\title{
ВЕРБАЛІЗАЦІЯ ОСНОВНИХ МОТИВІВ ТА ОБРАЗІВ ЗАСОБАМИ МОВИ (НА МАТЕРІАЛІ ЛЕМКІВСЬКИХ ЕМІГРАНТСЬКИХ ПІСЕНЬ)
}

Панцьо С. Є., Лісняк Н. І. Вербалізація основних мотивів та образів засобами мови (на матеріалі лемківських емігрантських пісень).

У статті визначаються й аналізуються основні мотиви, мовні образи та символічність лемківських емігрантських пісень. Звертається увага на образність мови пісень, на наявність діалектизмів, які створюють місцевий колорит.

Ключові слова: емігрантські пісні, мотиви, образи, символи.

Панцьо С. Е., Лисняк Н. И. Вербализация главных мотивов и образов средствами языка (на материале лемковских эмигрантских песен).

В статье определяются и анализируются основные мотивы, языковые образы, символика лемковских эмигрантских песен. Обращается внимание на образность речи песен, на наличие диалектизмов, творящих местный колорит.

Ключевые слова: эмигрантские песни, мотивы, образы, символы.

Pancyo S. J., Lisnyak N. I. Verbalization of main motifs and images by means of language (based on immigrant Lemkos songs).

In the article determined and analyzed the main motifs, linguistic images and symbolism of immigrant Lemkos songs. Attention is drawn to imagery language of songs and presence of dialecticism, that create local colour.

Key words: emigrant songs, motifs, images, symbols.

У народнопісенній спадщині українців своєрідне місце посідає лемківська пісня. Зафіксована у друкованих збірниках, вона розкриває особливості світогляду, життя, побуту етнографічної групи українського народу лемків. Адже саме народнопоетичне слово відображає шляхи розвитку людського розуму. Народнопісенна лексика містить не лише філософські знання народу, а й вербалізує його емоційний стан, почуття, оцінку.

Певні аспекти народнопісенної мови в україністиці розглядали I. Огієнко, А. Коваль, Л. Мацько, С. Срмоленко та ін. Протягом останніх років значно активізувалося вивчення мови української народної пісні. 3'явилися монографічні праці, статті, у яких досліджуються особливості народнопісенного слова, розкривається символічний світ українців, аналізується специфіка народнопісенного слова як одиниці художньоестетичної системи. Прикладом цього є відомі монографії Н. Данилюк [4], В. Гойсак [3], розвідки Л. Вакарюк [2; 7], С. Панцьо [7] та ін.

Ліро-епічна тональність народних пісень породжує символічні образи, які $\epsilon$ як загальнонаціональними, так і специфічними для народнопоетичного фольклору конкретного регіону. Символіка фольклорної поезії створена на основі історії етносу, на його традиціях, віруваннях, обрядах, людських 
почуттях і емоціях.

У мовній матерії лемківських пісень спостерігаємо різні образи, символіку залежно від їх ідейно-тематичних груп. Пісні про кохання, жовнірські та колискові були об'єктом досліджень. Мета нашої розвідки простежити вербалізацію основних мотивів мовних образів та символіку в емігрантських піснях лемків. Матеріалом для аналізу послужили лемківські пісні, вміщені у найбільшій і найкращій збірці «Антологія лемківської пісні», виданій у 2005 році у Львові за безпосередньої участі народної артистки України з Лемківщини Марії Байко [1].

С. Єрмоленко зазначає, що мова народної пісні «є скарбницею національного світобачення, своєрідною енциклопедією почуттів, художньоемоційною пам'яттю народу» [5, с. 118]. У пісні розкривається специфіка мови, говірки й такі грані слова, синтаксичних конструкцій, які, володіючи високим зарядом внутрішньої енергії, змушують замислюватися над особливостями народної творчості. Зі збірників пісень до нас донесено говіркову мову лемків з їх образами, символами.

У дискурсі емігрантських лемківських пісень вербалізуються різні мотиви, через них мовні образи, символіка. Тут подаються наочні картини, на яких зображена доля лемків, змушених їхати в чужий край на заробітки. Важливим є мотив еміграції. Пор. у пісні: $A$ дай мі, Боже, щзо думаю. / Я думаю вандрувати [1, с. 464]; Кой в нас превелика біда, / Не можна заробиц хліба, гей! [1, с. 466]. Мандрівка лемка у чужий край зумовлена бідністю: у гірських місцевостях мало доброї землі для вирощування зернових, городніх культур. Тому в емігрантських піснях правда життя звучить у сполуках заробляти хліба, заробити хліба: Бувайте здорові, мушу вас лишати, / Їду на чужину хліба заробляти [1, с. 468]. Ужиті дієслова в різних видових формах указують, з одного боку, на повернення додому (заробити), а з іншого, - на довготривале перебування в чужині, а нерідко й неповернення до рідної хати (заробляти): Деси в Гамериц̧и / Спочиват в землиции [1, с.463]. Відповідно до мети мандрівки часто вживаним є дієслово заробляти у різних граматичних формах: Иду зарабяц пінязі [1, с. 463].

У текстах емігрантських пісень чітко змальована наочна картина, яка змушує чоловіків, юнаків та й дівчат шукати заробітків в Америці: Гей, нема ту в нашім краю. / Гей, ничого доброго. // Ни пінязий, ни роботи, / Ни палюнки, ни хліба, / Гей, лем в тоту Америку. / Гей машеровац треба [1, с. 463].

Iз мотивом заробітчанства тісно пов'язаний символ хліба як найголовнішої їі, уособлення усіх статків [6, с. 618]. Лексема хліб у словосполученні хліба заробляти виступає символом щастя. Отже, цей вислів означає «шукати щастя».

У піснях звучить мотив смутку. У них відчутними є нарікання на долю. () С. Є. Панцьо, Н. І. Лісняк, 2013. 
Доля, як відомо, одухотворений образ. Вона в емігранта гірка: Спіткала мя гірка доля, не Гамерика [1, с. 462], інша: А тепер як вироснув, інша доля стала. / Пойхав я на чужину у ту Гамерику [1, с. 465].

Сум, туга за рідним краєм пронизує чи не всі пісні. Пор.: Шуми, вітре, шуми, буйний, на ліси, на гори, Мою смутну думку неси на лемківські двори... Ой, милая сторононько, я тебе не бачу, Так мі тяжко тут і смутно, хоч коли заплачу [1, с. 469].

В аналізованих текстах семантично навантажені лексеми бiда, тяжко, смуток, журба, жаль (превелика біда, жаль мі вас, мої верхи, смутна думка, тяжко жити, журбу збудиш). У народнопоетичному слові цього виду пісень панівною $є$ сема страждання, тому зазначені лексеми відзначаються частотою вживання. Ця сема реалізується і за допомогою фразеологічних одиниць. Як стверджує С. Срмоленко, важке життя, туга за рідною землею виливалися в заробітчан у пісні, у яких переважала відповідна фразеологія - відомі поширені вислови, пов'язані 3 лексемою сльози [5, с. 163]: Пор. також в емігрантських піснях лемків: Я машини пущу - нитки ся торгают, / А мене, мамусю, - слези заливают [1, с. 468]. Заливатися слізьми - це гірко плакати. У пісенних рядках наявні й інші фразеологізми, які підсилюють сему «страждання», зокрема руки заламувати. Наприклад: В Гамерици стежка шутрована,/ Ходит по ній мила заплакана, / Ходит-ходит, ручки заламує [1, с. 468].

Особливо виразно проступає в піснях мотив туги за рідним краєм. Живучи на чужині, лемки тужать за рідною батьківщиною, яка позначена в пісенних рядках лексемами край, сторона, земля: Ой жаль мі тя, рідна земле; Ой жаль мі тя, моя страно [1, с. 465]; Ой, мила сторононько, я тебе не бачу [1, с. 469]; Як ишов я з Гамерики до краю [1, с. 469]. Разом 3 тим слово край виступає синонімом до лексеми вдома. Пор., наприклад, у такому контексті: Гей, поӥхав мій миленький аж до Гамерики, Він ми висилає Звідти долярики, Боже мій! Гей, я їх заміняю на крайову п'ятку, Буду починала В краю господарку, Боже мій! [1, с. 467].

Зазначимо, що чужина також позначається словом край, але в поєднанні з прикметниками (чужий, гамерицкий), займенником (той), які протиставляються словосполученням наш край, старий край, свій край. Наприклад: На шіснаият рочків г чужсий край післала [1, с. 465]; A ma друга в старім краю гірко бідує [1, с. 462]; Полетів бим на край світа, / Як вітер, што в полі літат, гей! В Гамерицкий край [1, с. 466].

Як бачимо, у дискурсі емігрантських лемківських пісень вирізняється образ батьківщини. Вона для лемків є найбільшою духовною цінністю, хоч у пісенних рядках це слово не функціонує, а вжиті синоніми до нього (край, сторона, рідна земля).

Крім цих слів-понять, семантично навантаженими є слова рід, родина, як і назагал в українських народних піснях. Рід, родина для лемків, як і для 
українців різних територій, багато важать у житті. Ці лексеми репрезентують мотив відірваності від родини, руйнацію роду. Від’їзд у далеку Америку чи Канаду позбавляє емігранта не лише спілкування 3 родиною, а й їх руйнування. Пор. ... жсаль мі роду понехати (залишати) [1, с. 464]; Родинонько моя, зостаньте мі здрави / Юж ня не гвидите / I мого голосу юж не почуєте [1, с. 465]. Особливо промовистими є пісенні рядки, у яких змальовано прощання з родиною. Пор.: Проводили-сте мя аж за єдну годину, / Там я ся жсегнава зо свойом родином [1, с. 465]. Родина, як зазначає В. Жайворонок, «це традиційний символ душевного порятунку, затишку, ключова ланка родоводу» [6, с. 504]. Отже, від’їз одного з членів родини розриває цю ланку. Мотив прощання посилює сему страждання. Мандрівники прощаються 3 рідними: матір'ю (Прощцай, ненько моя рідна [1, с. 465]), батьками і сестрами (Там я ся жегнава з батьками, сестрами [1, с. 465]); Будь здрава, сестричко, / Не плачте, мамичко [1, с. 463], старою хатою (Прощай... ти стара хатино [1, с. 465]), горами (Бувайте здорови, мої рідні гори [1, с. 468]). Ужиті зменшено-пестливі деривати мамичко, сестричко, ненько засвідчують ніжне ставлення до батьків, міцність родинних стосунків.

Ліричним, з особливою звуковою та структурною організацією слів виступає пісенний текст, у якому йдеться про прощання мандрівника 3 коханою дівчиною: Буд здраве младеньке, / Дівчатко шварненьке, / Штом тя так миловав барз. // Ждий мене кусиіся, / Даст Бог, же вернуся... [1, с. 463]. Нанизування зменшено-пестливих слів різних частин мови 3 суфіксами -еньк-, -атк- $з$ ускладненою суфіксальною морфемою -ціс(я) у прислівнику створює ліричну картину - прощання закоханих. Римування прислівника кусиіся (трішечки) з дієсловом вернуся, тобто прийом звукового збігу -ся і -ся створює не що інше, як звуковий образ. Подібне явище відзначають дослідники в чумацьких та інших піснях [5, с. 158].

Вербалізація мовних образів, символів і мотивів $\epsilon$ загальнонародною, однак своєрідною з використанням діалектизмів, з уживанням у конкретному тексті на позначення різних понять, які характерні для лемків.

Своєрідним є фольклорний простір для емігрантських пісень. Він представлений такими одиницями: поле, ліси, бори, земля, стежка, дорога, вода, море. Вони становлять батьківщину емігранта, а також представляють його єдність із живою природою. Символом рідного краю виступає передусім земля, 3 якою тісно пов'язане життя лемків, адже в їхній місцевості землі для обробітку завжди було мало, тому вона по-особливому цінувалася. Емігрант, прощаючись із нею, називає ії ніжно землиця (Буд здрава, землице [1, с. 463]). Лемко поріднився з довкіллям свого краю горами, лісами. Тому у хвилини прощання майбутнього емігранта вони схвильовано шумлять, наче тривожаться за його долю в чужині: Замиміли ліси, заиуміли бори, / Бувайте здорови [1, с. 468]. Мандрівника зазвичай чекають труднощі в дорозі, а від’їзд в Америку пов’язаний із водою, що () С. Є. Панцьо, Н. І. Лісняк, 2013. 
викликало тривогу. Отже, символ води, моря - це далека, важка дорога: Як єм сідав на то море, / Струхніло мі серие моє. // Боже, Боже, як ся бою, / Як проплину тоту воду [1, с. 467]. Гори, ліси - це те середовище, у якому зростали лемки, тому розлучення з ними викликає жаль: Лем жаль мі вас, мої верхи / Зеленії, жаль [1, с. 466].

Лексема дорога в дискурсі емігрантських пісень трапляється рідко (дорога далека), але змушення вирушати в даль, долаючи перешкоди, $\epsilon$ не що інше, як важка дорога, яка не завжди символізує повернення додому. Пор.: Не поверну тату, мамо, юж до вас николи; ...юж мя не гвидите [1, с. 465]. Водночас емігрант прагне повернутися додому. Його не тішить в «Гамерици стежкка иутрована», бо він «у краю мусить житы», бо голову сім'ї чекає дружина, діти. Пор.: Дочкаш ти ся дочкаш, моя жено, дочкаш, / Як я домів приду, личко мі побочккаш [1, с. 470]; Як єм пришов до Кракова, / Чекала мя жена моя. / Діти мене не познали, / Бо од мене повтікали! // Діти, діми, я ваш тато, / Не било мя штири лята! [1, с. 467]. Діалектизми домів приду, дочкашся, не поверну по суті імпліцитно реалізують сему «дорога».

На противагу локалізованому простору в текстах емігрантських пісень, як і в піснях про кохання, трапляється і неозначений простір. Він виражається словом свіm, що, як стверджують дослідники, символізує життєву невизначеність [2, с. 45]. У пісенних рядках фольклору про еміграцію світ - це даль: Полетів бим на край світа [1, с. 466]; це також буття, існування: Хоча вже свої мами на світі не маю [1, с. 464].

У народнопісенних текстах виступають персоніфіковані образи окремих дерев: зелена ялина, стара сосна, дуб старий. Через вітер дівчина посилає звістку в рідний край. Пор.: Там ти скаже стара сосна $і$ вся деревина, Як там грало серце моє у світлу годину. Там ти скаже $i$ дуб старий, $i$ $\epsilon$ єен, і другий, Як я жила там з миленьким без журби, без туги [1, с. 469]. Як відомо, дуб символізує міцність роду, а в народних піснях - кохання [6, с. 204]. Сосна символізує зажурену жінку чи дівчину [6, с.571], ялина вічнозелене дерево, яке ототожнюється з молодістю ліричного героя - жінки.

Виразно й опоетизовано змальовано розмову емігрантів 3 вітром. Образ вітру наявний в українській народнопоетичній творчості. В. Жайворонок зазначає, що «вітер - це посланець, його посилають 3 вітанням, побажанням, зі звісткою; ...вітер може мати демонічну силу» [6, с. 101]. Зазвичай через нього посилаються додому вісті з чужини. У дискурсі аналізованих пісень з вітром порівнюється людина. Пор.: Полетів бим на край світа, / Як вітер, што в поли літат [1, с. 466]. Коли юнак прощається з рідною природою, то «вітер повіває», наче благословляє його на мандрівку. Але в разі, коли на чужині дівчина тужить за домівкою, вона посилає вітер у рідні місця і просить його бути буйним, иуміти. Наприклад: Шуми, вітре, иуми, буйний, на ліси, на гори [1, с. 469]. Жива природа представлена 
лише двома пташками - соловейком і сойкою. Соловейко символізує веселощі, радощі, любов, родинний затишок і милого [6, с. 561]: $A$ в садочку соловейко щцебетав пісоньки, / Розвивав ми пісоньками літа молоденькі [1, с. 469].

У пісенних рядках згадується лісовий перелітний птах сойка. Дослідники зазначають, що сойка «тримає ключі від вирію», що це «віщий птах», який віщує долю, а ще символізує невдаху [6, с. 560]. У пісні «Полетів бим на край світа» ліричний герой висловлює жаль за природою, за сойками, яких може покинути. Пор.: Ой, жсаль мі вас, сойки сиви, Штом вас плекав без три зими, Бо інакие бим поӥхав В Гамерицикий край [1, с. 466].

Нечасто, але доволі промовисто в тексті пісень виступають інші образи. Так, образ сім’ї створюють качур, качка, качечки. Пор.: Ой піду я на ставочок, там пливає сім качочок, Качур к качці підпливає, кожний свою пару має. А я бідний на чужині, марно згину в тій краӥні [1, с. 464].

Символом труднощів виступає камінь. Наприклад: Бо в чужсні тяжко жити, легше камінь поточити. // Камінь точу тай спочину, а в чужсині марно гину [1, с. 464].

Цікавим і своєрідним є образ думки. Як згусток енергії людини, через ліси, гори думка дівчини посилається у лемківські двори. Думкоюспогадом лине емігрантка в рідний край, до ялини, сосни, дуба, у свій садочок. У пісні «Шуми, вітре, шуми, буйний» спостерігаємо оживлену природу, серед якої «грало серцее» в гарні часи (світлу годину). Фразеологізм грало серцее символізує молоді, радісні, щасливі роки життя, як і фразеологізм світла година.

Ще одним цікавим образом у пісенних текстах є образ зламаної гілки, що символізує відірвану від роду молоду особу, яка відправляється в еміграцію. Так, у пісні «Зашуміли ліси» наявні рядки, які засвідчують розлуку зі своїм краєм і пов'язану з цим втрату веселості: Bimep повіває, суха галузь впала, / Юж веселіст моя навіки пропала [1, с. 468]. Отже, як суха галузка відпала $з$ дерева, так і відпадає від родини емігрант, бо він зісохне в чужині від праці, від журби і туги. Подібно до жовнірських, в емігрантських піснях зв'язок з рідними підтримується через листи, які, хоч і довго йдуть у Лемківщину, проте є втіхою для обох сторін. Відомо, що вже традиційним для українського народнопісенного фольклору $є$ вислів «дрібний лист писати». Пор. у лемківській пісні: Тівко часто до вас буду дробний листок писав, / І листовом том бесідом буду вас потіиав [1, с. 465].

Зменшено-пестлива форма листок у поєднанні зі сталим епітетом дробний підсилює важливість листування з ріднею. А словосполучення листова бесіда символізує розмову, що гріє душу i тішить серце «співрозмовників». У наведених рядках використано характерний для пісенної творчості засіб повтору - ужиті поруч спільнокореневі, споріднені слова листок, листовий. Сполука листова бесіда може виступати () С. Є. Панцьо, Н. І. Лісняк, 2013. 
метафоричною ознакою до дієслова потішати. I перед нами виникає картина спілкування емігранта з рідними. Словесна поетична образність у їі звукових, зорових картинах наближається, як справедливо зазначає С. Срмоленко, до музики й малярства [5, с. 158].

Серед наявних образів та символів у піснях виявлено образ хати, який уособлює родинне вогнище, благополуччя, гостинність [6, с. 616]. Цей образ маніфестований лексемами хата, хатина, хижа нерідко у сполученні з прикметниками: стара хатина, солом'яна хижа. Наприклад: Лем мі тя, моя хижно / Солом'яна, жаль. // Прощуай, село моє рідне, і хата, $і$ віра [1, с. 465]. Такі словосполучення також підкреслюють убогість мешканців гір.

Еміграція лемків - це не лише стражденна сторінка в їх історії, це і народження фольклору, зокрема пісенного, у якому відображені передусім сум, журба, туга за рідним краєм і водночас любов до рідної батьківщини, до родини, до рідного слова. Творці емігрантських пісень змалювали картини життя в чужині і вдома. Важка праця в Америці, Канаді та інших країнах часто ламала долі лемків. На зароблені гроші вони купували шматок поля, на якому не доводилося довго попрацювати, оскільки вони згодом були виселені з рідних місць і розселені в Україні, у Польщі. Частина лемків назавжди залишилася в еміграції. Там вони теж творили фольклор. Узірцем такої творчості $є$ пісня «Пісне моя українська», у якій у формі звертання звучить заклик до матері навчати на чужині дітей своїх пісень: Чуєи мамо-українко, /Хоч ти тут, в Канаді, /Учи дітей своїх пісень, / Вони будуть раді [1, с. 464].

Аналізований народнопоетичний контекст насичений етномаркованими образами, семантикою любові до рідного краю, тугою, семантикою страждання, які так влучно і майстерно втілені нерідко в діалектному мовленні. Низка діалектизмів жегнати (прощатися), побоцкати (поцілувати), зостаньте мі (залишіться), понехати (залишати), гвидіти (побачити), тівко (тільки) та ін. не тільки створюють місцевий, лемківський колорит, а й підсилюють основні мотиви, образи та символіку емігрантських пісень.

Отже, емігрантські пісні лемків пронизані сумом, тугою, жалем, тривогою, викликаними заробітчанством. Мовні образи, символіка та основні мотиви $є$ не лише наочністю еміграції, а й відображають внутрішній стан, кращі почуття цієї гірської людності, які вилилися в народнопоетичному слові невеликої кількості пісень. Звукова, словесна структура пісенних рядків забарвлена говірковими елементами, які правдиво й водночас опоетизовано змальовують важкі часи для однієї 3 етнографічних груп українського народу - лемків.

\section{Література}

1. Антологія лемківської пісні / [упорядник М. Байко]. - Львів, 2005. - 496 с.

2. Вакарюк Л. О. Образно-символічний потенціал лемківської пісні про кохання / Л. О. Вакарюк // Лемківський діалект у загальноукраїнському контексті // Studia 
methodologia. - Вип. 27. - Тернопіль : Ред.-видав. відділ ТНПУ імені Володимира Гнатюка, 2009. - С. 43-49.

3. Гойсак В. Мовна картина світу, відображена в народних колядках 3 Лемківщини / В. Гойсак. - Горлиця, 2010. - 286 с.

4. Данилюк Н. Поетичне слово в українській народній пісні : [монографія] / Н. О. Данилюк. - Луцьк : Волинський національний університет імені Лесі Українки, 2010. -512 c.

5. Єрмоленко С. Мова і українознавчий світогляд / С. Єрмоленко. - К., 2007. - 443 с.

6. Жайворонок В. Знаки української етнокультури : [словник-довідник] / В. Жайворонок. - К. : Довіра, 2006. - 703 с.

7. Панцьо С. Культурологічна вагомість соматичної лексики (на матеріалі лемківської пісні) / С. Панцьо, Л. Вакарюк // Наукові записки Вінницького державного педагогічного університету імені Михайла Коцюбинського. Серія : філологія (мовознавство) : зб. наук. праць / [гол. ред. Н. Л. Іваницька]. - Вип. 16. Вінниця : ТОВ «Фірма «Планер», 2012. - С. 155-162. 